\title{
Turning blight into bloom
}

As we become an ever more urban species, cities will be a crucial front in the fight against climate change. Scientists, architects and planners must join forces to make our metropolitan future clean and sustainable.

$H^{2}$ umanity has passed a milestone: more people live in cities than in rural areas. The current rate of urbanization is unprecedented in our history. In 1950, only $29 \%$ of people lived in cities; by $2050,70 \%$ are projected to do so - most of them in poorer countries. Among many other issues, this rapid concentration makes cities a front line in the battles against climate change and air pollution. Confronting the challenges of rampant urbanization demands integrated, multidisciplinary approaches, and new thinking.

Take the building boom associated with the increased wealth of urban areas, and its impact on greenhouse-gas emissions. In China alone, the United Nations Environmental Programme estimates that energy demand for heating homes built over the next decade could increase by some 430 terawatt-hours, or $4 \%$ of China's total energy use in 2003 . Worldwide, the energy consumed by buildings already accounts for around $45 \%$ of greenhouse-gas emissions.

Fortunately, researchers in Germany and elsewhere have already shown that they can reduce that energy consumption by $80-90 \%$, just by overhauling obsolete building designs and using existing technologies (see Nature 452, 520-523; 2008). These ultra-efficient buildings demand that planners, architects, engineers and building scientists work together from the outset, and require higher levels of expertise than conventional buildings. But such buildings are often cheaper than those built using conventional methods. Research is also needed to develop technologies, materials and energy concepts, but green building research today is fragmented and poorly funded.

Expanding cities must embrace such technologies and strategies - and not just in the developed nations. It may seem utopian to promote these innovations in emerging and developing-world megacities, many of whose inhabitants can barely afford a roof over their heads. But those countries have already shown a gift for technological fast-forwarding, for example, by leapfrogging the need for landline infrastructure to embrace mobile phones. And many poorer countries have a rich tradition of adapting buildings to local practices, environments and climates - a home-grown approach to integrated design that has been all but been lost in the West. They now have an opportunity to combine these traditional approaches with modern technologies.

Integrated thinking is also needed to mitigate urban air pollution, which is becoming a serious health and environmental risk in many regions - as shown by China's struggle to clean up Beijing's air for the Olympics. Understanding air pollution will require researchers from multiple disciplines, from atmospheric chemistry to meteorology, working over scales from street level to global (see page 142). And reducing it will require integrated policies for urban planning, transport and housing - not least to reduce the use of cars.
"Many poorer countries have a rich tradition of adapting buildings to local practices."
This unified approach is not entirely new: the Brazilian city of Curitiba has linked urban planning, transport and housing development for decades; a large majority of its nearly 2 million inhabitants now use public transport and recycle waste. But new city design and planning tools are making it considerably easier. Modern simulation software, for example, allows designers to do full structural analyses of buildings and model their energy balances in three dimensions. Likewise, geographical software allows planners to model the impact of planning scenarios on variables such as traffic and emissions.

Integrated thinking and planning requires a cultural shift: most urban development has been laissez-faire. Yet there are signs that such a shift has begun. In California, state lawmakers are considering a bill to restrict transportation subsidies to compact developments that reduce the need for car travel. If passed, this would be the first legislation in the United States to tie urban planning to the control of greenhouse gases. And China plans to build one of the world's first eco-cities off the coast of Shanghai. Dongtan aims to be free of cars, energy-independent - thanks to energy-efficient buildings, plus the extensive use of renewables and geothermal strategies for heating and cooling - and home to half a million people.

Such innovations need to be encouraged, expanded and accelerated - everywhere on the planet.

\section{Brave new worlds}

\section{A new series of essays looks back at scientific meetings that had world-changing consequences.}

reative ideas are not always solo strokes of genius, argues Ed Catmull, the computer-scientist president of Pixar and Disney Animation Studios, in the current issue of the Harvard Business Review. Frequently, he says, the best ideas emerge when talented people from different disciplines work together.
This week, Nature begins a series of six Essays that illustrate Catmull's case. Each recalls a conference in which a creative outcome emerged from scientists pooling ideas, expertise and time with others - especially policy-makers, non-governmental organizations and the media. Each is written by someone who was there, usually an organizer or the meeting chair. Because the conferences were chosen for their societal consequences, we've called our series 'Meetings that Changed the World'.

This week, François de Rose relives the drama of the December 1951 conference at the UNESCO headquarters in Paris that led to the creation of CERN, the European particle-physics laboratory based 